\title{
Stefano Lazzarin, «Balzac et le corps des nobles: à propos du Cabinet des Antiques»
}

\section{Marco Stupazzoni}

\section{(2) OpenEdition}

1 Journals

\section{Edizione digitale}

URL: https://journals.openedition.org/studifrancesi/26528

DOI: 10.4000/studifrancesi.26528

ISSN: 2421-5856

\section{Editore}

Rosenberg \& Sellier

\section{Edizione cartacea}

Data di pubblicazione: 1 avril 2007

Paginazione: 194

ISSN: 0039-2944

\section{Notizia bibliografica digitale}

Marco Stupazzoni, «Stefano Lazzarin, «Balzac et le corps des nobles: à propos du Cabinet des Antiques»», Studi Francesi [Online], 151 (LI | I) | 2007, online dal 30 novembre 2015, consultato il 23 novembre 2021. URL: http://journals.openedition.org/studifrancesi/26528 ; DOI: https://doi.org/ 10.4000/studifrancesi.26528

Questo documento è stato generato automaticamente il 23 novembre 2021.

\section{(c)}

Studi Francesi è distribuita con Licenza Creative Commons Attribuzione - Non commerciale - Non opere derivate 4.0 Internazionale. 


\title{
Stefano Lazzarin, «Balzac et le corps des nobles: à propos du Cabinet des Antiques»
}

\author{
Marco Stupazzoni
}

\section{NOTIZIA}

STEFANO LAZZARIN, «Balzac et le corps des nobles: à propos du Cabinet des Antiques», in Corps, littérature, société (1789-1900), sous la direction de Jean-Marie RouLIN, P. U. SaintÉtienne, 2005, pp. 175-189.

Se, nella prima metà dell'Ottocento, la rappresentazione letteraria della corporeità sia individuale sia quella direttamente riconducibile al sovrano subiscono una significativa evoluzione sotto la prospettiva storica, politica e sociale, Le Cabinet des Antiques di Balzac, come mostra bene S. Lazzarin, illustra, forse più di ogni altro testo della Comédie humaine, il processo di «métaphorisation du corps» (p.176), attraverso la rappresentazione delle figure di quel "petit faubourg Saint-Germain de province" che è il salotto aristocratico del marchese d'Esgrignon. Si tratta di corpi mummificati sintomatici di una «désuétude idéologique» e di una «obsolescence d'idées» (p.177) caratteristiche ormai dell'Ancien Régime. A questi “corps" polisemici che lasciano metaforicamente trasparire i segni indelebili di eventi storici, di forze sociali e intrighi politici fa da contraltare la figura del Re, simbolo ormai svuotato di ogni significato che «se soustrait à la vision; icône de la négation, il n'est évoqué que pour être aussitôt voilé par une réticence» (p. 189). 